\title{
Ecosystem carbon transit versus turnover times in response to climate warming and rising atmospheric $\mathrm{CO}_{2}$ concentration
}

\author{
Xingjie Lu ${ }^{1,2,3}$, Ying-Ping Wang ${ }^{3}$, Yiqi Luo ${ }^{2,4}$, and Lifen Jiang ${ }^{2}$ \\ ${ }^{1}$ School of Atmospheric Sciences, Sun Yat-sen University, Guangzhou 510275, China \\ ${ }^{2}$ Center for Ecosystem Science and Society, Department of Biological Sciences, \\ Northern Arizona University, Flagstaff 86011, USA \\ ${ }^{3}$ CSIRO Oceans and Atmosphere, Aspendale 3195, Australia \\ ${ }^{4}$ Department for Earth System Science, Tsinghua University, Beijing 100084, China
}

Correspondence: Xingjie Lu (xngj.lu@gmail.com)

Received: 7 April 2018 - Discussion started: 2 May 2018

Revised: 3 October 2018 - Accepted: 4 October 2018 - Published: 7 November 2018

\begin{abstract}
Ecosystem carbon (C) transit time is a critical diagnostic parameter to characterize land $\mathrm{C}$ sequestration. This parameter has different variants in the literature, including a commonly used turnover time. However, we know little about how different transit time and turnover time are in representing carbon cycling through multiple compartments under a non-steady state. In this study, we estimate both $\mathrm{C}$ turnover time as defined by the conventional stock over flux and mean $\mathrm{C}$ transit time as defined by the mean age of $\mathrm{C}$ mass leaving the system. We incorporate them into the Community Atmosphere Biosphere Land Exchange (CABLE) model to estimate $\mathrm{C}$ turnover time and transit time in response to climate warming and rising atmospheric $\left[\mathrm{CO}_{2}\right]$. Modelling analysis shows that both $\mathrm{C}$ turnover time and transit time increase with climate warming but decrease with rising atmospheric $\left[\mathrm{CO}_{2}\right]$. Warming increases $\mathrm{C}$ turnover time by 2.4 years and transit time by 11.8 years in 2100 relative to that at steady state in 1901 . During the same period, rising atmospheric $\left[\mathrm{CO}_{2}\right]$ decreases $\mathrm{C}$ turnover time by 3.8 years and transit time by 5.5 years. Our analysis shows that $65 \%$ of the increase in global mean $\mathrm{C}$ transit time with climate warming results from the depletion of fast-turnover $\mathrm{C}$ pool. The remaining $35 \%$ increase results from accompanied changes in compartment $\mathrm{C}$ age structures. Similarly, the decrease in mean $\mathrm{C}$ transit time with rising atmospheric $\left[\mathrm{CO}_{2}\right]$ results approximately equally from replenishment of $\mathrm{C}$ into fastturnover $\mathrm{C}$ pool and subsequent decrease in compartment $\mathrm{C}$ age structure. Greatly different from the transit time, the turnover time, which does not account for changes in either
\end{abstract}

$\mathrm{C}$ age structure or composition of respired $\mathrm{C}$, underestimated impacts of warming and rising atmospheric $\left[\mathrm{CO}_{2}\right]$ on $\mathrm{C} \mathrm{di-}$ agnostic time and potentially led to deviations in estimating land $\mathrm{C}$ sequestration in multi-compartmental ecosystems.

\section{Introduction}

The terrestrial ecosystem plays an important role in mitigation of climate change through sequestering carbon $(\mathrm{C})$ from the atmosphere. Terrestrial $\mathrm{C}$ storage is co-determined by $\mathrm{C}$ input and $\mathrm{C}$ transit time, which is defined as the mean age of C mass leaving the system (Luo et al., 2001; Taylor and Lloyd, 1992; Nir and Lewis, 1975; Sierra et al., 2016; Manzoni et al., 2009; Eriksson, 1971; Bolin and Rodhe, 1973). As transit time cannot be easily estimated from observation, its variant, $\mathrm{C}$ turnover time, has been commonly used in the literature (Sierra et al., 2016). A recent model intercomparison study indicated that a major cause of uncertainty in predicting future terrestrial $\mathrm{C}$ sequestration is the variation in $\mathrm{C}$ turnover time among the models (Friend et al., 2014). Up to $40 \%$ of soil $\mathrm{C}$ sequestration potential can be overestimated due to underestimation of $\mathrm{C}$ turnover time in current CMIP5 models (He et al., 2016). These examples highlight the importance of $\mathrm{C}$ turnover time in understanding $\mathrm{C}$ cycle uncertainties. However, the $\mathrm{C}$ turnover time has been mostly estimated with a conventional stock-over-flux method (Carvalhais et al., 2014; Chen et al., 2013; Yan et al., 2017), which was probably first introduced by Olson (1963) and based on 
a steady-state assumption. In response to climate change, terrestrial ecosystem $\mathrm{C}$ dynamics move away from steady states to dynamic disequilibrium (Luo and Weng, 2011). Estimation of $\mathrm{C}$ turnover time likely deviates from $\mathrm{C}$ transit time in response to climate change (Sierra et al., 2016). It is not clear how much the estimate of $\mathrm{C}$ turnover time deviates from mean $\mathrm{C}$ transit time and what causes their deviation under climate change.

The $\mathrm{C}$ transit time as the mean age of $\mathrm{C}$ mass leaving the system can be estimated only from age structure of $\mathrm{C}$ atoms in a multi-compartment ecosystem. In contrast, the $\mathrm{C}$ turnover time is estimated without any information of age structure of $\mathrm{C}$ atoms among compartments. Thus, $\mathrm{C}$ turnover time is equivalent to mean $\mathrm{C}$ transit time only in the autonomous (i.e. time-invariant) system at steady state (Sierra et al., 2016) with two conditions to be satisfied. The first condition is that $\mathrm{C}$ fluxes and turnover rates of individual pools do not change with time (i.e. time invariant or autonomous). The second is that $\mathrm{C}$ influx to each pool equals the $\mathrm{C}$ efflux from the pool (i.e. at steady state). However, the autonomous and steady-state conditions are usually too strict to completely meet for real-world ecosystems. For example, ecosystem $\mathrm{C}$ input via photosynthesis has diurnal variation, a seasonal cycle, and inter-annual variability. $\mathrm{C}$ turnover time also exhibits strong seasonal variation (Luo et al., 2017). With seasonal cycles and inter-annual variability in both $\mathrm{C}$ input and turnover time, the ecosystem $\mathrm{C}$ cycle is rarely at steady state and is rather mostly at dynamic disequilibrium (Luo and Weng, 2011). Therefore, $\mathrm{C}$ turnover time may not equal $\mathrm{C}$ transit time in the real world, especially when land $\mathrm{C}$ cycle is under transient dynamics in response to climate change.

The estimates of $\mathrm{C}$ transit time require information of $\mathrm{C}$ age structure in ecosystems so that the mean age of the $\mathrm{C}$ atoms at a time when they leave the system can be calculated (Manzoni et al., 2009). In a multi-compartmental ecosystem, the $\mathrm{C}$ age within each compartment is represented by a single compartment's mean $\mathrm{C}$ age and different compartments have different mean $\mathrm{C}$ ages (Rasmussen et al., 2016). Thus, the $\mathrm{C}$ transit time is the weighed mean of ages of $\mathrm{C}$ atoms leaving different compartments according to the fraction of $\mathrm{C}$ loss from each pool to the total $\mathrm{C}$ loss. In response to rising atmospheric $\left[\mathrm{CO}_{2}\right]$, increased $\mathrm{C}$ input of a young age into an ecosystem is usually allocated more to fast- than slowturnover pools, leading to changes in the $\mathrm{C}$ age structure of the ecosystem. The fast-turnover pools usually contribute more to respiratory loss than the slow pools. Thus, it is expected that rising atmospheric $\left[\mathrm{CO}_{2}\right]$ decreases $\mathrm{C}$ transit time due to both changes in the $\mathrm{C}$ age structure and fractions of different pools to total $\mathrm{C}$ loss from the ecosystem. Although it may change in response to rising atmospheric $\left[\mathrm{CO}_{2}\right]$ due to changes in both $\mathrm{C}$ fluxes and pools, $\mathrm{C}$ turnover time does not account for changes in the $\mathrm{C}$ age structure and the pool fractions of respiratory $\mathrm{C}$ loss over total ecosystem respiration. It is necessary to understand the theoretical deviation between $\mathrm{C}$ transit time and $\mathrm{C}$ turnover time under a non-steady state. In this study, we aim to answer following questions:

1. How do both $\mathrm{C}$ turnover time and $\mathrm{C}$ transit time change in response to climate warming and rising atmospheric $\left[\mathrm{CO}_{2}\right]$ ?

2. How much does the $\mathrm{C}$ turnover time deviate from $\mathrm{C}$ transit time under future climate change?

3. What mechanisms cause deviation between the two methods?

4. Which regions show the greatest deviations under different climate change scenarios?

To answer those questions, we incorporated a new algorithm into the Community Atmosphere Biosphere Land surface Exchange (CABLE) model (Wang et al., 2010, 2011) to calculate both $\mathrm{C}$ turnover time and transit time. We ran the modified CABLE model under three climate change scenarios, climate warming only, rising atmospheric $\left[\mathrm{CO}_{2}\right]$ only, and both climate warming and rising atmospheric $\left[\mathrm{CO}_{2}\right]$, to compare changes in $\mathrm{C}$ transit time with those in $\mathrm{C}$ turnover time.

\section{Materials and methods}

\subsection{The CABLE model}

CABLE is a global land surface model as described by Kowalczyk et al. (2006) and incorporates global carbon, nitrogen, and phosphorus cycles (Wang et al., 2010, 2011). This study does not activate phosphorus cycle in the model largely because phosphorus has minor impacts on $\mathrm{C}$ cycle (Zhang et al., 2011). Leaf photosynthesis, stomatal conductance, and heat and water transfer in CABLE are calculated using the two-leaf approach (Wang and Leuning, 1998).

Gross primary production (GPP) is calculated for both $\mathrm{C}_{3}$ and $\mathrm{C}_{4}$ plants (Farquhar et al., 1980; Kowalczyk et al., 2006). The Farquhar model is a biochemical model and modified in CABLE to calculate $\mathrm{CO}_{2}$ assimilation rate at canopy level as a minimum of three potential limitation processes of photosynthesis: light, enzyme, and C sink. Generally, all three of these photosynthetic limitations are positively related to maximal carboxylation rate $\left(V_{\mathrm{cmax}}\right)$ or maximal potential electron transport rate $\left(J_{\max }\right)$ and intercellular $\mathrm{CO}_{2}$ concentration $\left(C_{i}\right)$. Both $V_{\text {cmax }}$ and $J_{\max }$ are temperature dependent (Leuning, 2002) and are maximized at around $30^{\circ} \mathrm{C}$. Thus, in response to warming, the model usually predicts a positive response in GPP in cold and temperate regions but a negative response in GPP in hot regions. $C_{i}$ depends on the stomata conductance and atmospheric $\left[\mathrm{CO}_{2}\right]$. GPP in CABLE positively responds to rising atmospheric $\left[\mathrm{CO}_{2}\right]$. CABLE photosynthesis is also controlled by soil moisture. 
Table 1. Summary of scenarios and forcing data.

\begin{tabular}{|c|c|c|c|}
\hline Scenario name & $\begin{array}{l}\text { Simulation } \\
\text { abbreviation }\end{array}$ & Climate forcing & $\mathrm{CO}_{2}$ data \\
\hline Climate warming scenario & S1 & Climate warming $^{\mathrm{a}}$ & Pre-industrial $^{\mathrm{d}}$ \\
\hline $\mathrm{CO}_{2}$ direct effect scenario & S2 & Pre-industrial $^{\mathrm{b}}$ & $\mathrm{CO}_{2}$ increase $^{\mathrm{c}}$ \\
\hline Full effect scenario & S3 & Climate warming ${ }^{\mathrm{a}}$ & $\mathrm{CO}_{2}$ increase $^{\mathrm{c}}$ \\
\hline \multicolumn{4}{|c|}{$\begin{array}{l}\text { a Climate warming forcing data from } 1901 \text { to } 2005 \text { use the CRUNCEP dataset. The forcing data from } 2006 \text { to } \\
2100 \text { use CESM output under Representative Concentration Pathways with radiative forcing increased by } \\
8.5 \mathrm{~W} \mathrm{~m}^{-2} \text { (RCP8.5). } \\
\mathrm{b} \text { The pre-industrial climate forcing repeatedly uses } 1 \text {-year climatology data averaged over } 1901 \text { to } 1910 \text { from } \\
\text { the CRUNCEP dataset. } \\
{ }^{c} \mathrm{CO}_{2} \text { concentration data are from the } 200 \text {-year CMIP5 dataset under historical and future scenarios } \\
\text { (RCP8.5). } \\
\mathrm{d}^{\mathrm{R}} \text { The pre-industrial } \mathrm{CO}_{2} \text { concentration is from the CMIP5 dataset for the year } 1901 \text {. }\end{array}$} \\
\hline
\end{tabular}

Autotrophic respiration $\left(R_{\mathrm{a}}\right)$ in CABLE is also temperature dependent and follows the modified Arrhenius formula (Ryan, 1991; Sitch et al., 2003). At the canopy scale, $R_{\mathrm{a}}$ is proportional to vegetation nitrogen content and a temperature-related coefficient. $R_{\mathrm{a}}$ will positively respond to warming climate. Heterotrophic respiration $\left(R_{\mathrm{H}}\right)$ is proportional to litter and soil decomposition rate and $\mathrm{C}$ pool sizes. The decomposition rates in the model are controlled by soil temperature and water. The temperature response is based on a $Q_{10}$ equation. Decomposition rates will positively respond to warming. The water response function is from the daily time step ecosystem model (DAYCENT) (Kelly et al., 2000) and the decomposition rate positively responds to wetter soil conditions.

CABLE has three vegetation compartments (leaf, wood, and root), three litter compartments (metabolic litter, structure litter, and coarse wood debris), and three soil compartments (fast soil pool, slow soil pool, and passive soil pool) (Wang et al., 2010).

\subsection{Simulation design}

We use the meteorological datasets from the National Centers for Environmental Prediction and Climatic Research Unit (CRUNCEP) to drive our model. The meteorological inputs from 1901 to 2100 include temperature, specific humidity, air pressure, downward solar radiation, downward long-wave radiation, rainfall, snowfall, and wind speed. The meteorological variables of CRUNCEP data from 1901 to 2005 are interpolated from 6-hourly into hourly (Qian et al., 2006) and re-gridded from $0.5^{\circ} \times 0.5^{\circ}$ to $1.875^{\circ} \times 2.5^{\circ} \mathrm{spa}$ tial resolution. From 2006 to 2100 , the hourly meteorological variables are generated from the Community Earth System Model version 1.0 (CESM) (Li et al., 2016; Hurrell et al., 2013) for Representative Concentration Pathway (RCP) 8.5.

$\mathrm{C}$ storage for all three scenarios (climate warming, rising atmospheric $\left[\mathrm{CO}_{2}\right]$, and both together) is initialized at preindustrial steady states, which is achieved by a spin-up approach. The spin-up method cycles 10-year CRUNCEP data (1901-1910) to drive CABLE, with $\left[\mathrm{CO}_{2}\right]$ constant at the
1901 level. A semi-analytic solution is used to accelerate spin-up simulation (Xia et al., 2012).

The description of three scenarios in this study is summarized in Table 1. Simulation one (S1) fixes the atmospheric $\left[\mathrm{CO}_{2}\right]$ but uses changing climate forcing. Simulation two (S2) fixes climate forcing but increases atmospheric $\left[\mathrm{CO}_{2}\right]$. Simulation three $(\mathrm{S} 3)$ uses both changing climate forcing and increasing atmospheric $\left[\mathrm{CO}_{2}\right]$.

\subsection{Calculation of mean ecosystem $\mathrm{C}$ age}

Mean $\mathrm{C}$ age is defined as the mean time elapsed since $\mathrm{C}$ atoms (current in the system) entered the system, which is important for understanding $\mathrm{C}$ transit time described below. Following Rasmussen et al. (2016), mean C age $(\bar{a})$ can be formulated

$\bar{a}(t)=\frac{\sum_{i=1}^{d} a_{i}(t) x_{i}(t)}{\sum_{i=1}^{d} x_{i}(t)}$.

In Eq. (1), $a_{i}$ represents the mean age of $\mathrm{C}$ in the $i$ th compartment, $x_{i}$ represents $\mathrm{C}$ pool size of the $i$ th compartment, and $d$ is the total number of $\mathrm{C}$ compartments.

Mixing fresh $\mathrm{C}$ input into old ecosystem $\mathrm{C}$ may reduce the mean ecosystem $C$ age. Meanwhile, $C$ remaining in the system will age with time. As shown by Rasmussen et al. (2016), dynamics of mean compartment $\mathrm{C}$ age can be described by the following differential equation:

$$
\begin{aligned}
\frac{\mathrm{d} a_{i}(t)}{\mathrm{d} t} & =1 \\
& +\frac{\sum_{j=1}^{d}\left(a_{j}(t)-a_{i}(t)\right) b_{i j} k_{j}(t) x_{j}(t)-a_{i}(t) s_{i}(t)}{x_{i}(t)} .
\end{aligned}
$$

In Eq. (2), $s_{i}(t)$ is the direct $\mathrm{C}$ input rate from net primary production (NPP) to the $i$ th compartment in $\mathrm{g} \mathrm{C} \mathrm{m}^{-2} \mathrm{yr}^{-1}$, $b_{i j}$ is the proportion of decomposed carbon from the $j$ th compartment to be transferred to the $i$ th compartment. $k_{j}$ is 
the decomposition rate of the $j$ th compartment; the unit is per year. Thus, change in compartment $\mathrm{C}$ age depends on $\mathrm{C}$ aging, network $\mathrm{C}$ transfers among pools with different ages, and $\mathrm{C}$ input. Note that this equation works only for linear models.

With a time step $\Delta t$, the $\mathrm{C}$ transferred from the $j$ th compartment to the $i$ th compartment $\left(F_{i j}\right)$ equals $b_{i j} k_{j}(t) x_{j}(t) \Delta t$ and $\mathrm{C}$ input $\left(S_{i}\right)$ equals $S_{i}(\mathrm{t})=\mathrm{s}_{i}(\mathrm{t}) \Delta t$, Eq. (2) can be rewritten in a finite-element form to represent $\mathrm{C}$ age dynamics:

$\Delta a_{i}(t)=\Delta t+\frac{\sum_{j=1}^{d}\left(a_{j}(t)-a_{i}(t)\right) F_{i j}-a_{i}(t) S_{i}(t)}{x_{i}(t)}$.

In Eq. (3), the first term, $\Delta t$, indicates natural $\mathrm{C}$ aging. the second term, $\frac{\sum_{j=1}^{d}\left(a_{j}(t)-a_{i}(t)\right) F_{i j}-a_{i}(t) S_{i}(t)}{x_{i}(t)}$, represents the mean age change of the $i$ th compartment due to mixing with transferred $\mathrm{C}$ from other compartments or external $\mathrm{C}$ input (i.e. NPP).

After the C cycle spin-up, we obtain the steady-state C ages in each compartment by solving Eq. (2) with the Euler method. The changes of mean compartment $\mathrm{C}$ age are less than $0.1 \%$ between two successive cycles.

\subsection{Ecosystem C transit time}

$\mathrm{C}$ transit time is defined as the average time for a $\mathrm{C}$ atom to spend in the ecosystem until its exit, or the time from entering the ecosystem to leaving the ecosystem (or residence time; Luo et al., 2001). For a multiple-compartment system, the mean $\mathrm{C}$ transit time, $\bar{\tau}_{\text {ts }}$, can be calculated using the following equation (Rasmussen et al., 2016):

$\bar{\tau}_{\mathrm{ts}}(t)=\frac{\sum_{i=1}^{d} a_{i}(t) x_{i}(t)\left(\sum_{j=1}^{d} b_{j i}\right) k_{i}(t)}{\sum_{i=1}^{d} x_{i}(t)\left(\sum_{j=1}^{d} b_{j i}\right) k_{i}(t)}$.

When $i=j, b_{j i}$ equals -1 , indicating one unit of $\mathrm{C}$ exited from the $i$ th compartment. When $i \neq j, b_{j i}$ represents the proportion of exited $\mathrm{C}$ of the $i$ th compartment transferred to the $j$ th compartment. $\sum_{j=1}^{d} b_{j i}=0$ when the exited $\mathrm{C}$ from the $i$ th compartment is fully transferred to all the other compartments, such as litterfall transferring from plant to litter compartments, without $\mathrm{C}$ loss. $\sum_{j=1}^{d} b_{j i}<0$ when the exited $\mathrm{C}$ from the $i$ th compartment is partly transferred to the other compartments, such as litter or soil C decomposition, with the rest lost to the atmosphere via respiration. The denominator is the total amount of $\mathrm{C}$ loss from the ecosystem. The numerator is the sum of products of respired $\mathrm{C}$ mass and $\mathrm{C}$ age.

\subsection{Components of $\mathrm{C}$ transit time and their changes}

Equation (4) can be reorganized as

$\bar{\tau}_{\mathrm{ts}}(t)=\sum_{i=1}^{d} a_{i}(t) f_{\mathrm{hr}, i}(t)$,

when we define the fraction of the total $\mathrm{C}$ loss from the $i$ th compartment $\left(f_{\mathrm{hr}, i}\right)$, hr represents heterotrophic respiration as

$$
f_{\mathrm{hr}, i}(t)=\frac{x_{i}(t)\left(\sum_{j=1}^{d} b_{j i}\right) k_{i}(t)}{\sum_{i=1}^{d} x_{i}(t)\left(\sum_{j=1}^{d} b_{j i}\right) k_{i}(t)} .
$$

Equation (5) indicates that ecosystem $\mathrm{C}$ transit time consists of products of two components: compartment $\mathrm{C}$ age $\left(a_{i}\right)$ and the fractional composition of respired $\mathrm{C}\left(f_{\mathrm{hr}, i}\right)$. Compartment $\mathrm{C}$ age as represented by Eq. (2) changes due to $\mathrm{C}$ mixing with $\mathrm{C}$ in other compartments or external input.

According to Eq. (5), the change in ecosystem $\mathrm{C}$ transit time $\bar{\tau}_{R}$ can be attributed to the change in compartment $\mathrm{C}$ age (change in $\mathrm{C}$ age structure) and the change in respired $\mathrm{C}$ composition as (see the Supplement for details)

$$
\begin{aligned}
\Delta \bar{\tau}_{\mathrm{ts}}(t) & =\sum_{i=1}^{d} a_{i}(t) \Delta\left(f_{\mathrm{hr}, i}(t)\right)+\sum_{i=1}^{d} f_{\mathrm{hr}, i}(t) \Delta\left(a_{i}(t)\right) \\
& +o\left(a_{i}(t) f_{\mathrm{hr}, i}(t)\right) .
\end{aligned}
$$

The first term in Eq. (6) refers to $\mathrm{C}$ transit time change due to change in respired $\mathrm{C}$ composition. If the fraction of respired $\mathrm{C}$ from fast-turnover pool decreases, the mean ecosystem $\mathrm{C}$ transit time may increase because more respired $\mathrm{C}$ comes from slow-turnover pools with older $\mathrm{C}$ ages. The second term refers to $\mathrm{C}$ transit time change due to change in compartment $\mathrm{C}$ age structure. Under elevated $\mathrm{CO}_{2}$, for example, young $\mathrm{C}$ enters a compartment more than it leaves. $\mathrm{C}$ in the compartment becomes younger (i.e. young $\mathrm{C}$ replenishment). Subsequently, mean ecosystem $\mathrm{C}$ transit time will decrease. The third term refers to residuals that cannot be explained by the previous two terms.

In this study, the $\mathrm{C}$ age dynamics and diagnostics represented by Eqs. (1)-(6) are implemented into CABLE global simulations. During our analysis of results, $\mathrm{C}$ age and transit time are averaged at different spatial scales, i.e. grid cell scale, latitudinal scale, and global scale. Pool sizes $\left(x_{i}\right)$, pool ages $\left(a_{i}\right)$, and pool-to-pool fluxes $\left(F_{i j}\right)$ in Eqs. (1)-(6) uses the grid cell mean, latitudinal mean, and global mean of each compartment to calculate three different scales of $\mathrm{C}$ age and transit time. Therefore, the arithmetic average of $\mathrm{C}$ age or transit time at each grid cell (e.g. Fig. 1a) does not equal the global average of $\mathrm{C}$ transit time (e.g. Fig. 3a). 
(a)

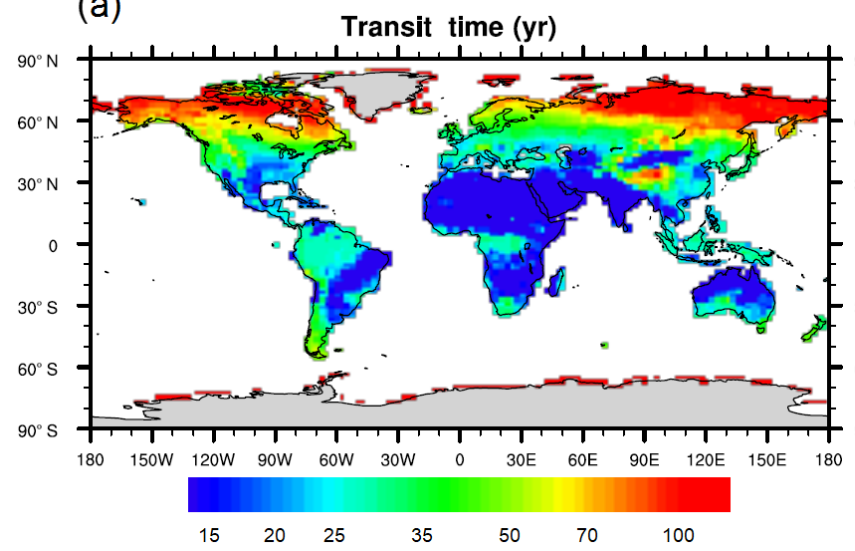

(b)

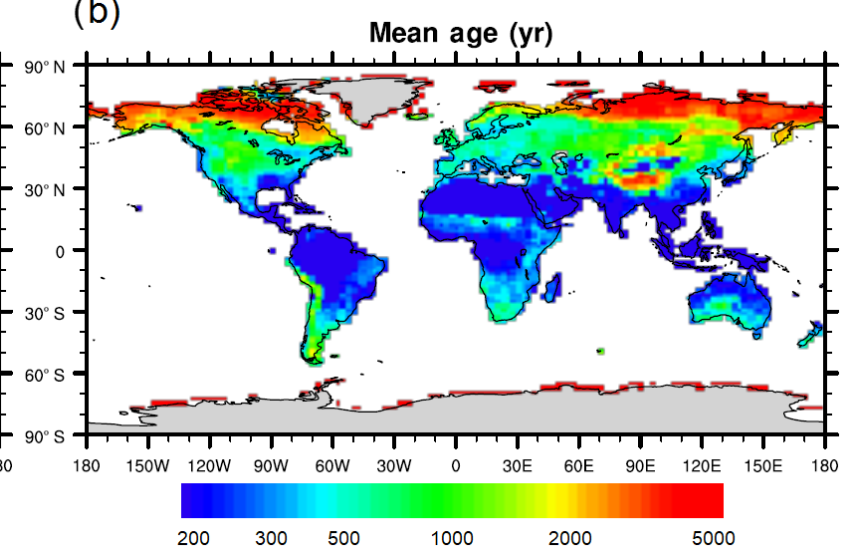

Figure 1. Global maps of (a) carbon transit time and (b) mean carbon age are the average over 1901 to 1910 in each grid cell.

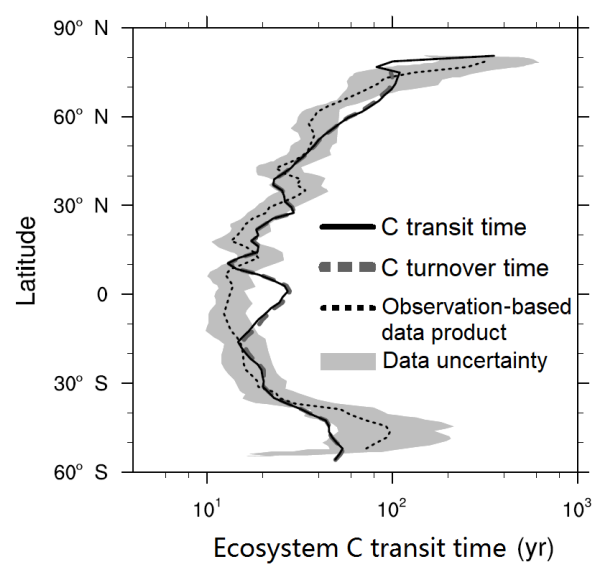

Figure 2. Validation of simulated latitudinal variation pattern in ecosystem $\mathrm{C}$ transit time. Comparison of the mean ecosystem $\mathrm{C}$ transit time from 1982 to 2005 as estimated in this study with the estimates from observation (Carvalhais et al., 2014) and simulated $\mathrm{C}$ turnover time from CABLE. The grey area indicates the uncertainty range of observation-based data. $\mathrm{C}$ transit time theoretically equals $\mathrm{C}$ turnover time only at steady state. To ensure the comparison is valid, we assumed, which is also assumed by some other ecological studies (Trumbore, 2000), that ecosystem C cycle during the data-covered period (1982 to 2005) is closed to the steady state. In addition, the global $\mathrm{C}$ balance data also support our assumption. In the 1980s and 1990s, global land C uptake from the Global Carbon Project (GCP) is about $0.8 \mathrm{GtC} \mathrm{yr}^{-1}$ with an uncertainty of $0.6 \mathrm{GtC} \mathrm{yr}^{-1}$, which is not significantly different from zero (Le Quéré et al., 2018).

\section{Results}

\subsection{Global steady-state patterns of ecosystem C transit time}

The global ecosystem $\mathrm{C}$ transit time at steady state generally shows a latitudinal variation pattern (Fig. 1). The high values (greater than 70 years) are simulated not only in highlatitude regions, such as northern Russia, northern Europe, and northern Canada but also in high-altitude regions such as the Tibetan Plateau. Small values in C transit time (less than 30 years) are simulated in tropical rainforest, such as Amazon forest, Conga forest, and Indonesian forest. Ecosystem $\mathrm{C}$ transit times in some grasslands in middle-south Africa, south America, the southern Great Plains of the US, and central northern Australia (savanna) are sometimes even smaller than those in tropical forest. The spatial patterns of the mean ecosystem $\mathrm{C}$ age are quite similar to the patterns of $\mathrm{C}$ transit time. However, the magnitude is significantly higher than ecosystem $\mathrm{C}$ transit time. The mean ecosystem $\mathrm{C}$ age ranges from 118 to 7952 years, whereas ecosystem $\mathrm{C}$ transit time ranges only from 13 to 341 years.

The global latitudinal pattern of $\mathrm{C}$ transit time in 19822005 is consistent with the observation-based pattern of turnover time (Fig. 2). The latter is estimated at each grid cell globally using the stock-over-flux method to divide ecosystem C storage by GPP (Carvalhais et al., 2014). The magnitude of the estimate is mostly within the uncertainty range of the observation-based pattern. We compare estimated C transit time in 1982-2005 with the turnover time, partly to match modelled values with contemporary observations and partly due to the fact that terrestrial $\mathrm{C}$ cycle is still approximately at a quasi-steady state between 1982 and 2005. Over the 1980s and 1990s, the annual average of global net land carbon sink estimated from the Global Carbon Project (GCP) is about $0.8 \mathrm{GtC} \mathrm{yr}^{-1}$ with an uncertainty of $0.6 \mathrm{GtC} \mathrm{yr}^{-1}$. As a reference, the annual average of net land carbon sink in the most recent decade (2007-2016) is $2.3 \mathrm{GtC} \mathrm{yr}^{-1}$ with an uncertainty of $0.7 \mathrm{GtC} \mathrm{yr}^{-1}$ (Le Quéré et al., 2018). The net change of global land carbon in the 1980s and 1990s is not that significant, which indicates the land $\mathrm{C}$ cycle has not moved too far away from the steady state. Moreover, the simulated latitudinal pattern of $\mathrm{C}$ transit time almost overlaps with $\mathrm{C}$ turnover time, showing that $\mathrm{C}$ cycle is still near the 

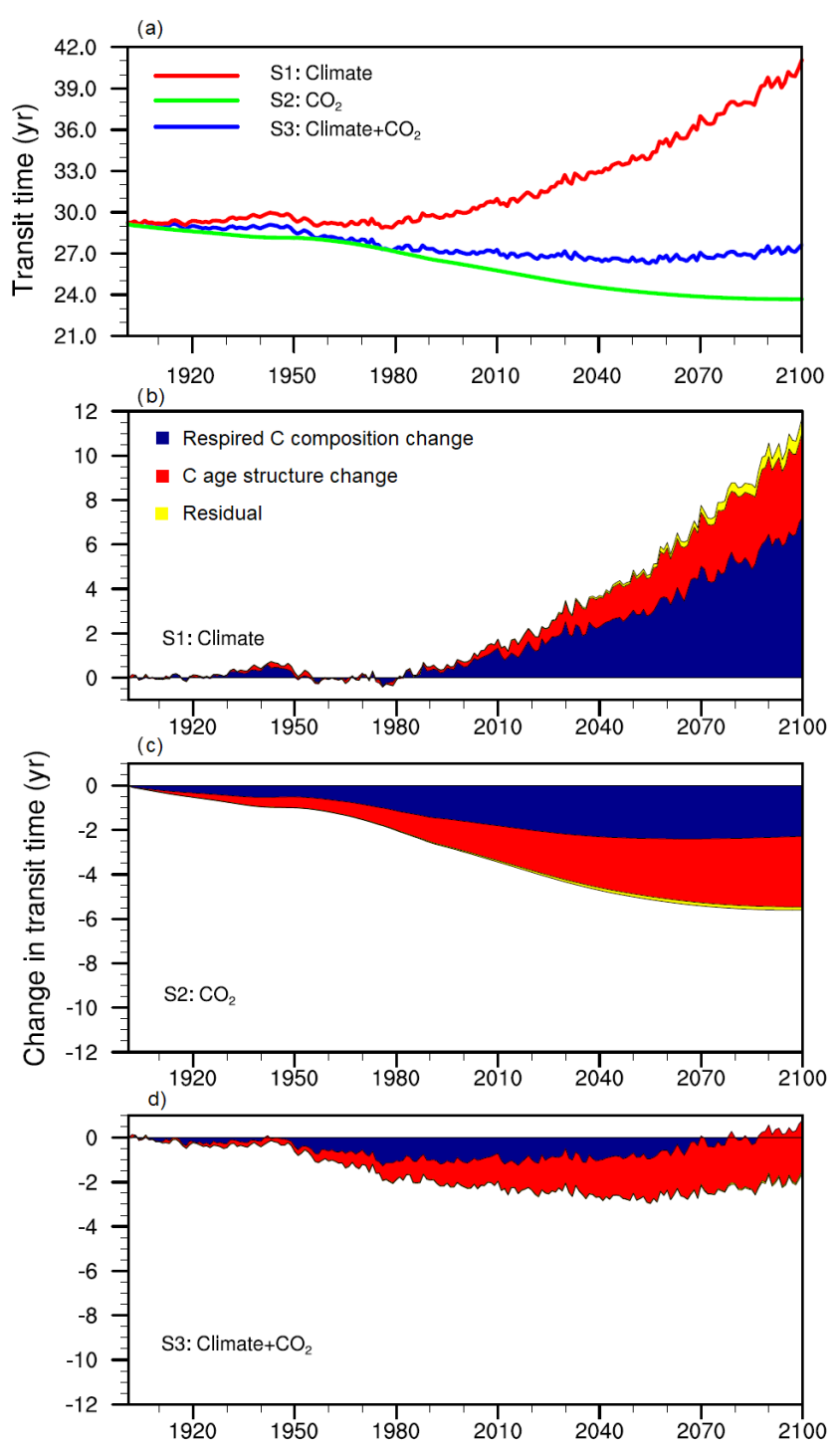

Figure 3. CABLE simulates changes of global $\mathrm{C}$ transit time for each of the three scenarios in (a) $\mathrm{S} 1$ : climate warming scenario (red line), S2: rising atmospheric $\left[\mathrm{CO}_{2}\right]$ scenario (green line), and S3: combined climate warming and rising atmospheric $\left[\mathrm{CO}_{2}\right]$ scenario (blue line). The changes in global ecosystem $\mathrm{C}$ transit time are separated into three contributions based on Eq. (6): contribution from respired $\mathrm{C}$ composition change, contribution from $\mathrm{C}$ age structure change, and residual (b-d).

steady state at present day. Annual $\mathrm{C}$ turnover time theoretically equals $\mathrm{C}$ transit time when the $\mathrm{C}$ cycle is close to steady state (Sierra et al., 2016).

\subsection{Responses of global mean $\mathrm{C}$ transit time to climate change}

In the 200-year simulation, mean global ecosystem $\mathrm{C}$ transit time increases by 11.8 years in response to climate warming (S1) and decreases by 5.6 years in response to rising at- mospheric $\left[\mathrm{CO}_{2}\right]$ (S2) (Fig. 3a). When climate warming and rising atmospheric $\left[\mathrm{CO}_{2}\right]$ force together $(\mathrm{S} 3), \mathrm{C}$ transit time decreases by 1.6 years. The increase in $\mathrm{C}$ transit time in $\mathrm{S} 1$ is not significant in the 20th century but substantial in the $21 \mathrm{st}$ century. Oppositely, the decrease in $\mathrm{C}$ transit time in S2 is steady before 2060 but slows down afterward. Mean $\mathrm{C}$ transit time in $\mathrm{S} 3$ decreases but with a smaller magnitude than that for $\mathrm{S} 2$ in the 21 st century.

Across all three scenarios, the majority (over 93.4\%) of changes in $\mathrm{C}$ transit time can be explained by two combined changes in compartment $\mathrm{C}$ age structure and respired $\mathrm{C}$ composition. Changes in the compartment $\mathrm{C}$ age structure and the respired $\mathrm{C}$ composition both significantly contribute to the total change in global $\mathrm{C}$ transit time. However, the contribution fraction varies among the three scenarios at different times. In the climate warming scenario $(\mathrm{S} 1)$, respired $\mathrm{C}$ composition changes contribute about $70 \%$ of the increase in $\mathrm{C}$ transit time in the 21 st century (Fig. 3b). In the rising atmospheric $\left[\mathrm{CO}_{2}\right]$ scenario $(\mathrm{S} 2)$, respired $\mathrm{C}$ composition change and $\mathrm{C}$ age structure change contribute equally (Fig. 3c). When coupling climate warming and rising atmospheric $\left[\mathrm{CO}_{2}\right]$ together in $\mathrm{S} 3$, respired $\mathrm{C}$ composition change significantly contributes only in the middle of the 200-year simulation (around the year 2000) and a little at the end of the 21 st century. The contribution of $\mathrm{C}$ age structure change to the change in $\mathrm{C}$ transit time gradually increases.

The increase in $\mathrm{C}$ transit time in the climate warming scenario (S1) is the most significant from low-latitude regions in South America and Africa (Fig. 4a). Respired C composition change explains most of these regional changes (Fig. 4c). The decrease in $\mathrm{C}$ transit time in the rising atmospheric $\left[\mathrm{CO}_{2}\right]$ scenario $(\mathrm{S} 2)$ is evenly simulated all over the world (Fig. 4d). Respired C composition change also plays an important role in most regions except for North Africa with little vegetation coverage. The $\mathrm{C}$ transit time in the combined climate warming and rising atmospheric $\left[\mathrm{CO}_{2}\right]$ scenario $(\mathrm{S} 3)$ mostly decreases in the Northern Hemisphere but increases in some tropical grassland regions in South America and Africa (Fig. 4g). In those regions where $\mathrm{C}$ transit time decreases, compartment $\mathrm{C}$ age structure change due to fresh $\mathrm{C}$ replenishment explains most of the change in $\mathrm{C}$ transit time.

Note that the response under combined effects (S3) is not a sum of those from individual effects (S1 plus S2). The nonadditive response to climate warming and rising atmospheric $\left[\mathrm{CO}_{2}\right]$ is probably due to their interactions, which have been commonly found in many ecological studies (Norby and Luo, 2004; Luo et al., 2008; Leuzinger et al., 2011; Campbell et al., 1997; Zhang et al., 2016).

\subsection{Global $\mathrm{C}$ turnover time and its deviation}

Similar to the changes in $\mathrm{C}$ transit time, the global $\mathrm{C}$ turnover time increases with climate warming and decreases with rising atmospheric $\left[\mathrm{CO}_{2}\right]$ (Fig. 5a). However, the magnitude substantially differs between these two methods (Figs. 3a, 


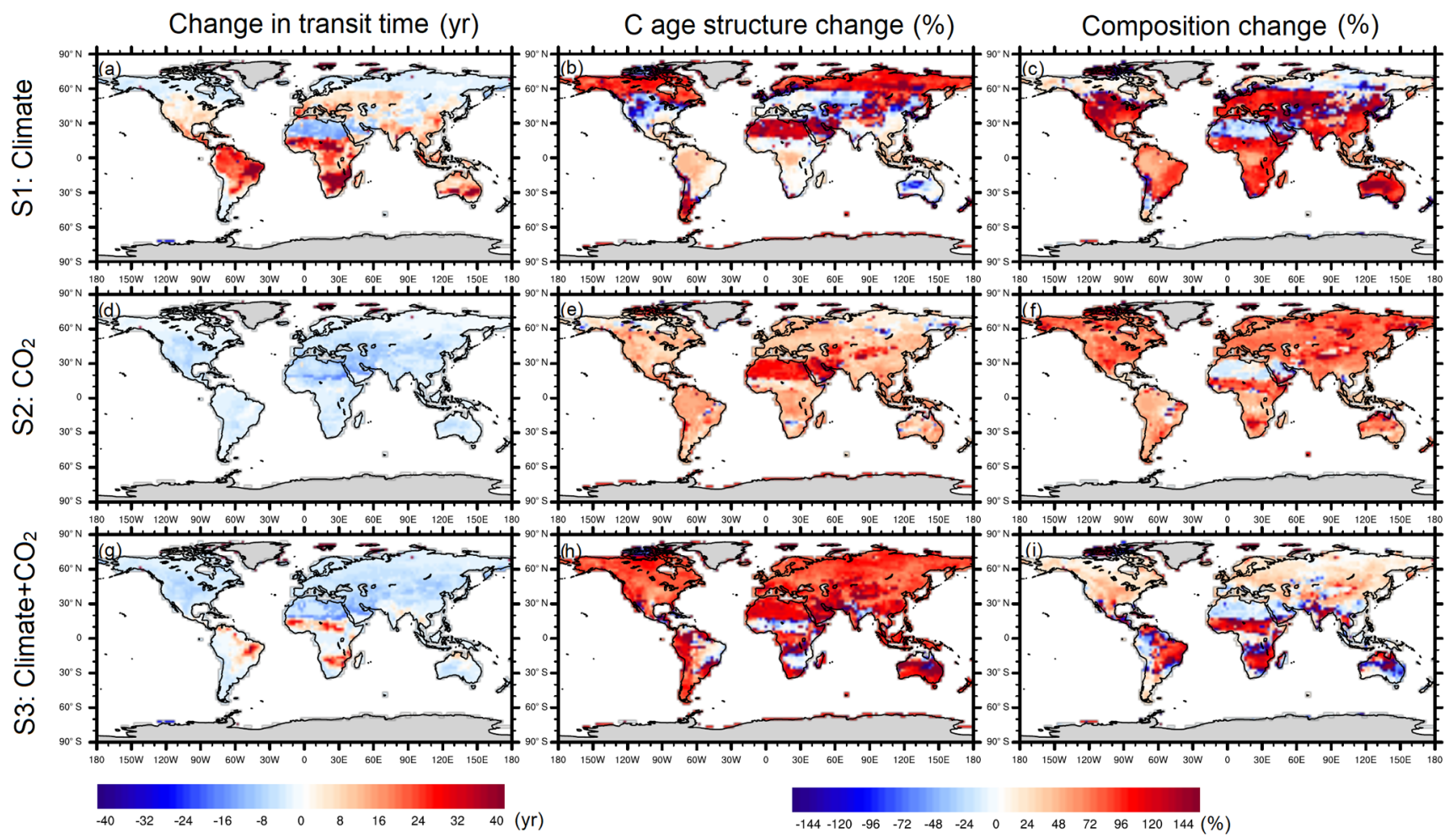

Figure 4. Global map of the change in $\mathrm{C}$ transit time in (a) $\mathrm{S} 1$ : climate warming scenario, (d) $\mathrm{S} 2$ : rising atmospheric $\left[\mathrm{CO}_{2}\right]$ scenario, and (g) S3: combined climate warming and rising atmospheric $\left[\mathrm{CO}_{2}\right]$ scenario. In these three scenarios, contribution from $\mathrm{C}$ age structure change and contribution from respired $\mathrm{C}$ composition change are also estimated in relation to the change in $\mathrm{C}$ transit time (S1: a and $\mathbf{c} ; \mathrm{S} 2$ : e and f; $\mathrm{S} 3: \mathbf{h}$ and $\mathbf{i})$. The calculation of the contribution from $\mathrm{C}$ age structure change and contribution from respired $\mathrm{C}$ contribution change is based on Eq. (6). The positive contribution indicates the $\mathrm{C}$ age structure change or composition change leads to $\mathrm{C}$ transit time change in the same direction.

5a). In response to climate warming (S1), global ecosystem $\mathrm{C}$ turnover time increases by only 2.4 years at the end of the simulation, which is only one-fifth of the increase in C transit time (11.8 years). In response to rising atmospheric $\left[\mathrm{CO}_{2}\right](\mathrm{S} 2)$, global $\mathrm{C}$ turnover time decreases by 3.7 years, whereas $\mathrm{C}$ transit time decreases by 5.6 years. In response to the coupled scenario (S3) in which climate warming and rising atmospheric $\left[\mathrm{CO}_{2}\right]$ force together, global ecosystem $\mathrm{C}$ turnover time decreases by 4.5 years, while $\mathrm{C}$ transit time decreases by only 1.6 years.

In 1901, the global $\mathrm{C}$ turnover time is about 0.5 year longer than the $\mathrm{C}$ transit time (Figs. 3a, 5a). Theoretically, $\mathrm{C}$ turnover time equals transit time when land $\mathrm{C}$ cycle is at steady state. The offset at the initial state of simulations probably results from $\mathrm{C}$ seasonal cycles, which are not at steady state. The underestimates of the change in $\mathrm{C}$ turnover time relative to $\mathrm{C}$ transit time increase in the climate warming scenario (S1) by up to 9.4 years in the end of the 21 st century, which is $79.6 \%$ of the total increase in $\mathrm{C}$ transit time (Fig. 5b). In the rising atmospheric $\left[\mathrm{CO}_{2}\right]$ scenario (S2), the deviation constantly grows to about 1.9 years, $27.7 \%$ of the underestimated decrease in $\mathrm{C}$ turnover time. In the cli- mate warming and rising atmospheric $\left[\mathrm{CO}_{2}\right]$ scenario (S3), the change in $\mathrm{C}$ turnover time is overestimated by 2.9 years or $181.1 \%$ relative to the change in $\mathrm{C}$ transit time in 2100 (Fig. 5b, c).

\subsection{Latitudinal variation in $\mathrm{C}$ turnover time and its deviation}

Latitudinal patterns in $\mathrm{C}$ transit time and $\mathrm{C}$ turnover time at the initial state in 1900 are nearly the same. Steady-state estimates are from 20 years in low latitudes and 100 years in high latitudes (Fig. 6a, d). However, significant deviation still exists in high latitudes (north of $60^{\circ} \mathrm{N}$ and south of $50^{\circ} \mathrm{S}$ ) (Fig. $6 \mathrm{~g}$ ) because seasonal soil freeze-thaw processes in this region lead to a strong seasonal cycle of soil decomposition and violate the steady-state assumption of the $\mathrm{C}$ turnover time. The underestimates of $\mathrm{C}$ turnover time can be up to 10 years in high-latitude regions, which is about $8 \%$ of $\mathrm{C}$ transit time. In other areas, deviation of turnover time is less than 0.5 years.

Changes in $\mathrm{C}$ turnover time and $\mathrm{C}$ transit time deviate in different regions in response to climate warming (S1) (Fig. 6b, c, e, f). In temperate and tropical regions, $\mathrm{C}$ tran- 


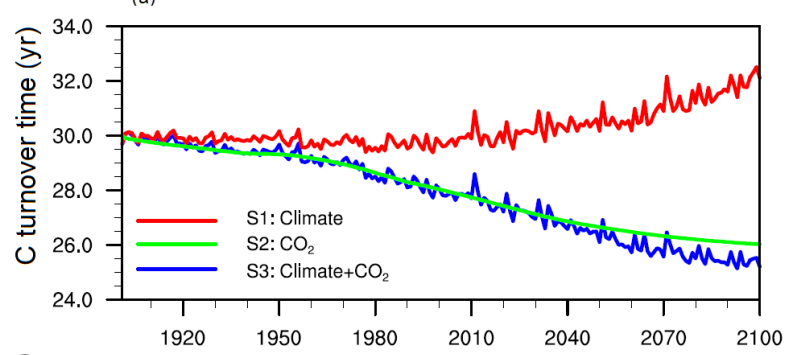

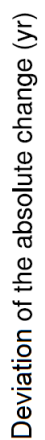
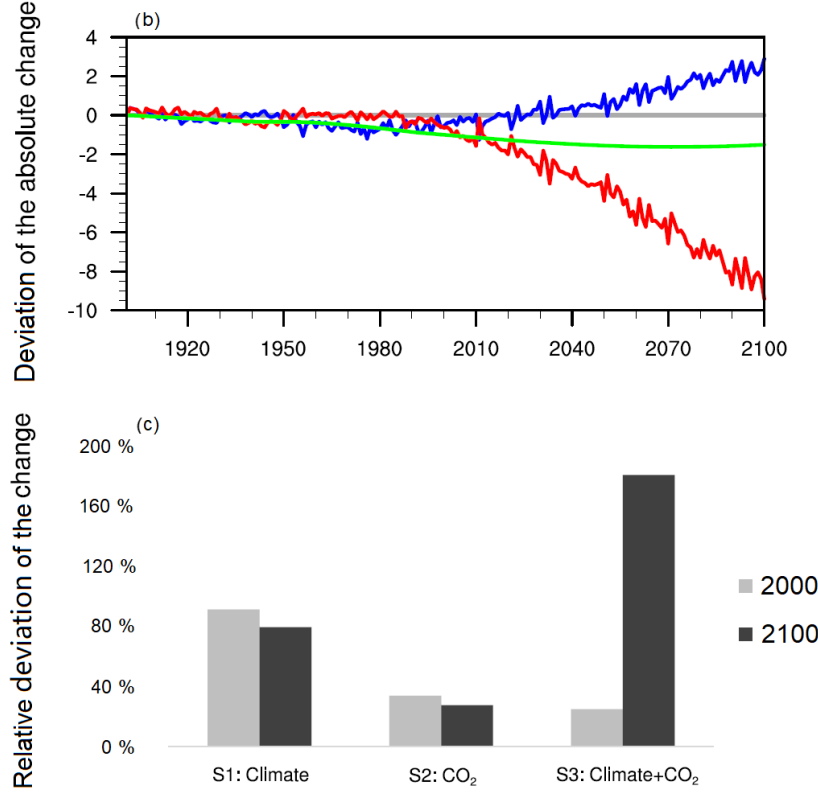

Figure 5. (a) Changes of global $\mathrm{C}$ turnover time (stock over flux) in $\mathrm{S} 1$ : climate warming scenario (red line), S2: rising atmospheric $\left[\mathrm{CO}_{2}\right]$ scenario (green line), and $\mathrm{S} 3$ : combined climate warming and rising atmospheric $\left[\mathrm{CO}_{2}\right]$ scenario (blue line). (b) The deviation of the change in $\mathrm{C}$ turnover time $\left(\Delta \tau_{\mathrm{to}}\right)$ is estimated relative to the change in $\mathrm{C}$ transit time $\left(\Delta \tau_{\mathrm{ts}}\right):\left(\left|\Delta \tau_{\mathrm{to}}\right|-\left|\Delta \tau_{\mathrm{ts}}\right|\right)$. Positive indicates more change in $\mathrm{C}$ turnover time than $\mathrm{C}$ transit time. The grey line represents the reference of no deviation. (c) The relative deviation of the change in $C$ turnover time in the years 2000 and 2100 is also estimated relative to the change in $C$ transit time: $\frac{\left(\left|\Delta \tau_{\mathrm{to}}\right|-\left|\Delta \tau_{\mathrm{ts}}\right|\right)}{\left|\Delta \tau_{\mathrm{ts}}\right|} \times$ $100 \%$.

sit time significantly increases, while $\mathrm{C}$ turnover time also increases but at a much smaller magnitude. In the tropics, $\mathrm{C}$ transit time increases by 13 years in 2100 , up to $60 \%$ of the initial value in 1900 , whereas $\mathrm{C}$ turnover time increases by only 2 years. In the high-latitude region, $\mathrm{C}$ transit time slightly decreases (Fig. $6 \mathrm{~b}$ and c) but $\mathrm{C}$ turnover time significantly decreases by several decades in the high latitudes (Fig. 6f). In some regions between 40 and $60^{\circ} \mathrm{N}, \mathrm{C}$ transit time increases but turnover time decreases in response to climate warming. $\mathrm{C}$ turnover time overall changes less than $\mathrm{C}$ transit time in the $\mathrm{S} 1$ scenario. Warming-induced changes in $\mathrm{C}$ turnover time are underestimated by $5 \%$ at the high lati- tudes of the Southern Hemisphere and up to $50 \%$ at the low latitudes (Fig. 6h), which ranges from 2 to 29 years (Fig. 6i).

In response to rising atmospheric $\left[\mathrm{CO}_{2}\right](\mathrm{S} 2)$, both $\mathrm{C}$ turnover time and transit time decrease. The magnitude of changes for both of them is generally greater at the midlatitudes than at either low or high latitudes (Fig. 6b, e). At most latitudes, $\mathrm{C}$ turnover time decreases less than $\mathrm{C}$ transit time, leading to a positive deviation (Fig. 6h, i). The deviation of the change is higher in low than high latitudes. In response to rising atmospheric $\left[\mathrm{CO}_{2}\right]$, the underestimate of the decrease in $\mathrm{C}$ turnover time is at most 2 years in absolute deviation or $10 \%$ in relative deviation (Fig. 6h, i).

In the climate warming and rising atmospheric $\left[\mathrm{CO}_{2}\right]$ scenario (S3), $\mathrm{C}$ turnover time and $\mathrm{C}$ transit time decrease at most of the latitudinal regions except for some tropic areas (Fig. b, 6c, e, f). The decrease in $\mathrm{C}$ turnover time is more than that in $\mathrm{C}$ transit time (Fig. 6h, i). Especially in high latitudes, the difference in changes is much more significant. $\mathrm{C}$ turnover time is reduced by up to 3 decades (Fig. 6f) or $35 \%$ (Fig. 6e), whereas $\mathrm{C}$ transit time shows nearly no relative changes. Deviation in these areas can be up to 27 years (Fig. 6i).

\section{Discussion}

\subsection{C transit time and its two components}

Changes in $\mathrm{C}$ transit time can be explained by its two components: the respired $\mathrm{C}$ composition and compartment $\mathrm{C}$ age structure. The first component is to account for different contributions of respired $\mathrm{C}$ from different pools to total ecosystem C loss. Previous studies have demonstrated that pathways of respiring $\mathrm{C}$ from multiple compartments are variably controlled by the global change factor (Luo et al., 2001). Results from this study provide more spatial details about where $\mathrm{C}$ transit time changes due to respired $\mathrm{C}$ composition change. For example, over $80 \%$ of the increase in $\mathrm{C}$ transit time under warming is explained by respired $\mathrm{C}$ composition change in the South American grassland region (Fig. 4a). In contrast, change in respired $\mathrm{C}$ composition only accounts for approximately $10 \%$ of the increase in $\mathrm{C}$ transit time under warming in the boreal and high-latitude regions of North America.

The second component is the $\mathrm{C}$ age structure, primarily from change in mean $\mathrm{C}$ age of the individual pool modified by the relative fraction of each pool. In the coupled climate warming with rising atmospheric $\left[\mathrm{CO}_{2}\right]$ scenario $(\mathrm{S} 3), \mathrm{C}$ age structure change primarily contributes to the $\mathrm{C}$ transit time response in most global regions in 2100 (Fig. 4h). In this scenario, mean ecosystem $C$ transit time decreases by 1.6 years. The decrease in $\mathrm{C}$ transit time results from increased young $\mathrm{C}$ uptake with rising atmospheric $\left[\mathrm{CO}_{2}\right]$, which is more than the increased young $\mathrm{C}$ loss with warming. A previous study has also shown that models with multiple pools usually have a more heterogeneous $\mathrm{C}$ age structure and thus can store 

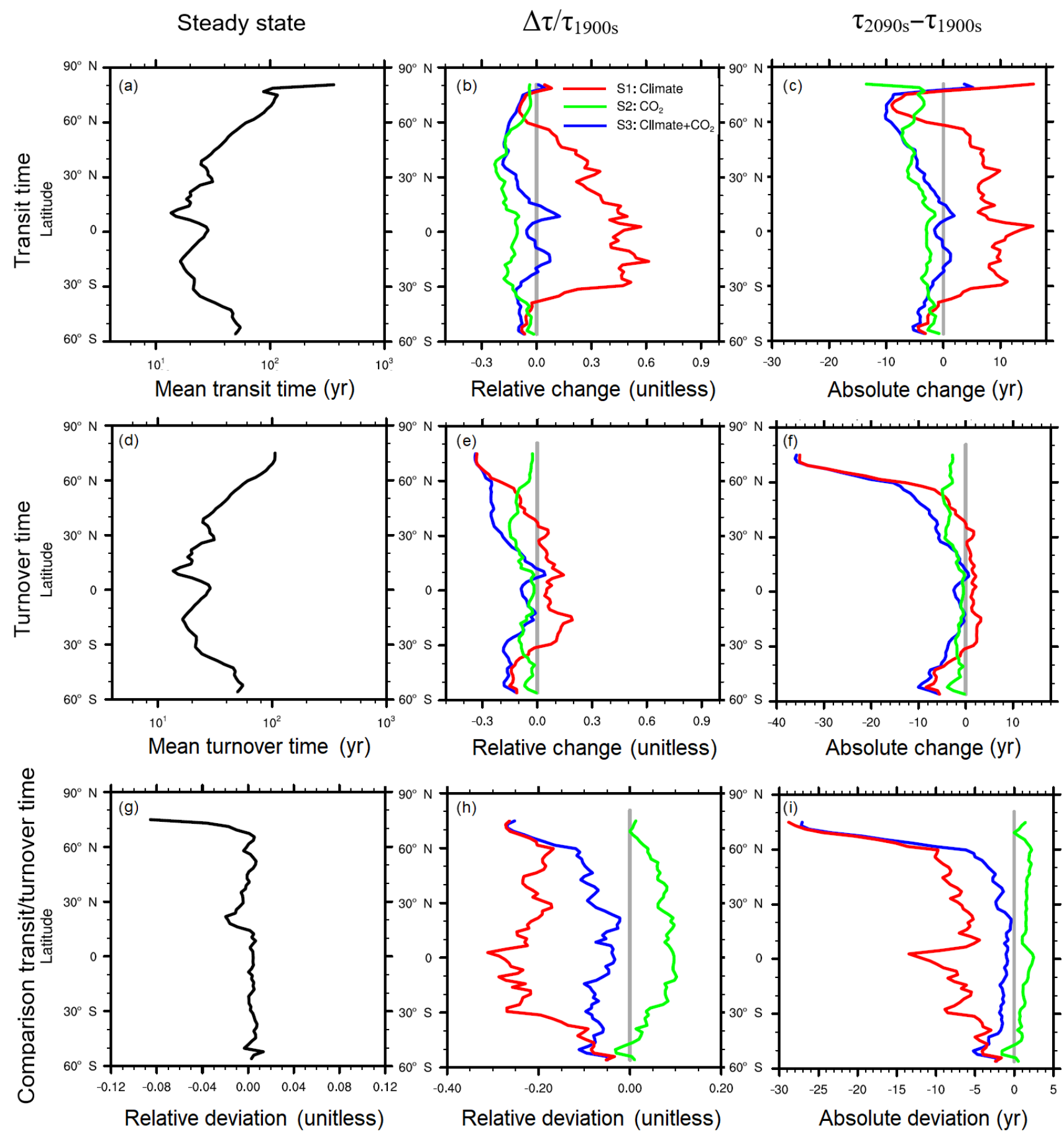

Figure 6. (a) Latitudinal variation in $\mathrm{C}$ transit time $\left(\tau_{\text {transit }}\right)$ at steady state and $(\mathbf{b}, \mathbf{c})$ its change are compared to (d-f) $\mathrm{C}$ turnover time $\left(\tau_{\mathrm{to}}\right)$. The changes between the $2090 \mathrm{~s}$ and $1900 \mathrm{~s}$ are estimated by $(\mathbf{c}, \mathbf{f})$ absolute value: $\Delta \tau=\left(\tau_{2090 \mathrm{~s}}-\tau_{1900 \mathrm{~s}}\right)$ and by $(\mathbf{b}, \mathbf{e})$ relative value: $\Delta \tau_{\mathrm{r}}=\frac{\Delta \tau}{\tau_{1900 \mathrm{~s}}}$. (g) The deviation of $\mathrm{C}$ turnover time relative to $\mathrm{C}$ transit time is estimated by $\left(\tau_{\text {to }}-\tau_{\text {ts }}\right) / \tau_{\text {ts }}$ at steady state. Relative to $\mathrm{C}$ transit time, the deviation of the change in $\mathrm{C}$ turnover time is estimated by (h) absolute deviation $\left(\left|\Delta \tau_{\text {to }}\right|-\left|\Delta \tau_{\text {ts }}\right|\right)$ and (i) relative deviation in $\frac{\left(\left|\Delta \tau_{\mathrm{to}}\right|-\left|\Delta \tau_{\mathrm{ts}}\right|\right)}{\mid \Delta \tau_{\mathrm{ts}}}$. All variables are compared in $\mathrm{S} 1$ : only climate warming scenario (red line), S2: rising atmospheric $\left[\mathrm{CO}_{2}\right]$ scenario (green line), and S3: combined climate warming and rising atmospheric $\left[\mathrm{CO}_{2}\right]$ scenario (blue line). Grey lines in (b), (c), (e), and (f) represent the reference lines of no change and those in (h) and (i) represent the reference line of no deviation. 
extremely old C than a single pool model (Manzoni et al., 2009).

\subsection{Deviation arising from estimated $\mathrm{C}$ turnover time}

C turnover time has been widely used to quantify the ecosystem $\mathrm{C}$ cycle partly because both ecosystem $\mathrm{C}$ storage and C flux can be easily measured (Sanderman et al., 2003; Chen et al., 2013; Carvalhais et al., 2014; McCulley et al., 2004; Raich and Schlesinger, 1992; Yan et al., 2017). The C turnover time has been theoretically shown to equal $\mathrm{C}$ transit time at steady state but they deviate under non-steady states (Sierra et al., 2016). This study illustrates how much deviation occurs between $\mathrm{C}$ transit time and $\mathrm{C}$ turnover time in response to three scenarios of climate change. Our results show that even at initial steady state, global ecosystem $\mathrm{C}$ turnover time is slightly greater than $\mathrm{C}$ transit time by $3 \%$. This is because the steady state reached by spin-up does not mean the terrestrial C cycle system is completely at equilibrium. Seasonal variations in ecosystem $\mathrm{C}$ uptake and turnover still lead to periodical oscillation of the terrestrial $\mathrm{C}$ cycle.

The deviation between $\mathrm{C}$ transit time and turnover time also indicates to what extent that turnover time can properly represent time characteristics in the $\mathrm{C}$ cycle. In the climate warming and rising atmospheric $\left[\mathrm{CO}_{2}\right]$ scenario $(\mathrm{S} 3)$, the deviation does not increase significantly until 2050. The modelled latitudinal pattern of present-day $\mathrm{C}$ transit time matches the $\mathrm{C}$ turnover time estimated from observations well (Carvalhais et al., 2014). This indicates that the stock-over-flux estimates are still useful at present day. However, the deviation between $\mathrm{C}$ transit time and turnover time remarkably increases after 2050 (Fig. 5b). Then it requires caution when we use the $\mathrm{C}$ turnover time for estimating $\mathrm{C}$ sequestration in multiple compartmental ecosystems.

In transient state, the changes in $\mathrm{C}$ transit time and $\mathrm{C}$ turnover time differ the most in the climate warming scenario (S1). Tropical and high-latitude regions contribute the most to the deviation (Fig. 6h, i). In tropical and subtropical regions, $\mathrm{C}$ transit time increases by about $60 \%$ (Fig. $6 \mathrm{~b}$ ) while $\mathrm{C}$ turnover time increases by $20 \%$ or less (Fig. 6e). The great difference between changes in $\mathrm{C}$ transit time and turnover time is due to their different assumptions. In response to climate warming, composition change in respired $\mathrm{C}$ contributes most to the change in $\mathrm{C}$ transit time in tropical regions. However, $\mathrm{C}$ turnover time assumes all ecosystem $\mathrm{C}$ as one homogenous pool, even if both plant and soil $\mathrm{C}$ can be extremely heterogeneous. This homogeneity assumption ignores the composition changes in respired $\mathrm{C}$, which causes up to $80 \%$ of change in $\mathrm{C}$ transit time.

In high-latitude regions, $\mathrm{C}$ transit time slightly decreases by up to $10 \%$, whereas $\mathrm{C}$ turnover time considerably decreases by over $30 \%$ in response to climate warming. Warming significantly increases soil respiration due to permafrost thaw, whereas the change in permafrost ecosystem $\mathrm{C}$ pool size is relatively small. Thus, $\mathrm{C}$ turnover time significantly decreases. $\mathrm{C}$ transit time slowly responds to climate warming because the young $\mathrm{C}$ input added to permafrost ecosystems is relatively small compared to large $\mathrm{C}$ storage in this area and $\mathrm{C}$ age structure does not change much. These big deviations between $\mathrm{C}$ turnover time and $\mathrm{C}$ transit time in tropical and permafrost regions suggest that future $\mathrm{C}$ cycle analysis based on turnover time likely leads to strong deviations as it does not represent transient $\mathrm{C}$ dynamics in multi-pool ecosystems.

\subsection{C transit time versus turnover time under other global change scenarios}

This study has illustrated how $\mathrm{C}$ transit time and turnover time deviate under climate warming and rising atmospheric $\left[\mathrm{CO}_{2}\right]$ scenarios. Those deviations may become even bigger under other global change scenarios. For example, land use change and fire can drive ecosystems out of steady state to be at disequilibrium (Luo and Weng, 2011). Clear-cutting of forest or forest fire removes at least the aboveground wood $\mathrm{C}$ pools and thus greatly changes both the total $\mathrm{C}$ stock and $\mathrm{NPP}$, leading to a large change in $\mathrm{C}$ turnover time (Wang et al., 1999; Zhou and Luo, 2008). Clear-cutting of forest or forest fire also changes age structure and composition of respired $\mathrm{C}$ from different pools within the ecosystem, resulting in change in $\mathrm{C}$ transit time. Such a disturbance usually drives the ecosystem to a stronger degree of disequilibrium than climate change does. The deviation between turnover time and transit time should be bigger under a severe disturbance than climate change since our results have indicated that $\mathrm{C}$ transit time and turnover time deviates more significantly when an ecosystem is further away from equilibrium (Fig. 5).

In contrast to the static vegetation distribution used in CABLE, natural vegetation distribution may change over time in the real world. $\mathrm{C}$ transit time and turnover time may further deviate under natural vegetation dynamics. However, whether forest will expand or die back in a future warming world is still quite unknown. Previous studies come to various conclusions due to their focus on different areas with different methods (Masek, 2001; Soja et al., 2007; Cox et al., 2004, 2013). Nevertheless, most bioclimatic models consistently suggest temperate and boreal biomes rapidly increase in area under warming (Kirilenko and Solomon, 1998). If the forest species, which stores more $\mathrm{C}$ in slow-turnover tissue, takes over the grass species, which stores more $\mathrm{C}$ in fastturnover tissue, the expansion of forest may increase $\mathrm{C}$ transit time significantly. However, $\mathrm{C}$ turnover time, by lumping all different $\mathrm{C}$ compartments together, may underestimate such changes.

In the real world, the land $\mathrm{C}$ cycle is always at dynamic disequilibrium due to cyclic environmental conditions (e.g. diurnal, seasonal, and interannual variability), directional global change (e.g. climate warming, rising atmospheric $\mathrm{CO}_{2}$ concentration, altered precipitation, and nitrogen deposition), recursive disturbance-recovery cycles, shifted cli- 
matic and disturbance regimes, and vegetation changes (Luo and Weng, 2011). Thus, the estimated C turnover time is expected to differ from the $\mathrm{C}$ transit time at any time point and at any spatial location. The degree of deviation between $\mathrm{C}$ turnover time and transit time may vary.

In addition to various agents that cause an ecosystem to be at disequilibrium, deviation between estimated $\mathrm{C}$ transit time and turnover time also depends on model structure. Vertically resolved soil $\mathrm{C}$ models, for example, include vertical C mixing and depth-dependent $\mathrm{C}$ decomposition rates (Koven et al., 2013; Huang et al., 2018). Representation of vertically resolved processes likely increases soil heterogeneity. When warming induces deep soil thaw and increases deep soil decomposition, the fraction of respired $\mathrm{C}$ from the deep layer with old $\mathrm{C}$ increases. The $\mathrm{C}$ transit time together with a vertically resolved model may substantially increase, whereas $\mathrm{C}$ turnover time, which implicitly assumes the ecosystem to be one homogeneous pool, may not respond much.

\subsection{Estimation of $\mathrm{C}$ transit time in the real world}

Previous studies have argued that $\mathrm{C}$ transit time is conceptually sounder than $C$ turnover time (Rasmussen et al., 2016; Sierra et al., 2016). In this study, we have shown that the $\mathrm{C}$ turnover time can substantially deviate from the transit time in response to climate change and other environmental changes. However, $\mathrm{C}$ turnover time can be easily calculated from $\mathrm{C}$ stock over flux, both of which can be easily measured. In contrast, $\mathrm{C}$ transit time cannot be easily estimated from field measurements. Equation (5) indicates that we need data from measurement of mean $\mathrm{C}$ ages $\left(a_{i}\right)$ and fractional composition of respired $\mathrm{C}\left(f_{\mathrm{hr}, i}\right)$ in individual $\mathrm{C}$ pools in order to calculate mean ecosystem C transit time $\left(\bar{\tau}_{\text {ts }}\right)$. Neither $a_{i}$ nor $f_{\mathrm{hr}, i}$ have been widely measured in field. Thus, our research community faces a tremendous challenge to estimate a conceptually sound and scientifically important parameter.

In the past, radiocarbon ${ }^{14} \mathrm{C}$ has been used to quantify mean $\mathrm{C}$ ages of various litter and soil pools (Gaudinski et al., 2000). Measured soil respiration in response to elevated $\mathrm{CO}_{2}$ treatment in Duke Forest has been decomposed to various fractional composition using a deconvolution method or inverse analysis (Luo et al., 2001). It appears that estimation of $\mathrm{C}$ transit time in real-world ecosystems requires measurement of isotope signatures in different litter and soil fractions together with measurement of respiration from soil surface and soil components. Those measurements, together with many other datasets, may need to be analysed to estimate mean $\mathrm{C}$ ages, fractional composition of respired $\mathrm{C}$ in individual $\mathrm{C}$ pools, and then mean ecosystem $\mathrm{C}$ transit time $\left(\bar{\tau}_{\text {ts }}\right)$ using some innovative methods, such as data assimilation.

Estimating $\mathrm{C}$ transit times in the real world can help constrain projections in land $\mathrm{C}$ sequestration because internal timescales of the carbon cycle are a major source of model uncertainty (Friend et al., 2014; He et al., 2016). Our study has shown that the change in $\mathrm{C}$ transit time can be separated into two components, $\mathrm{C}$ composition change and $\mathrm{C}$ age change. Assessment of the two components would provide additional constraints on model projections. Many of the ecosystem pools, such as leaf C, wood C, root C pool, litter C pools, and soil $\mathrm{C}$, can be measured separately. They provide plenty of information to constrain ecosystem C composition change. Isotope data from each of those ecosystem components also can offer information to constrain the mean compartment age. Although discrete soil C pools may not be easy to separate, many datasets from field and laboratory measurements have been used to constrain multi-pool soil carbon models by using data assimilation techniques (Liang et al., 2018; Xu et al., 2006). To constrain C transit time through its two components with observation, modelled $\mathrm{C}$ cycle and land $\mathrm{C}$ sequestration can be significantly improved.

\section{Conclusions}

This study explores how global ecosystem $\mathrm{C}$ transit time deviates from the turnover time under climate warming and rising atmospheric $\left[\mathrm{CO}_{2}\right]$. Although both global ecosystem $\mathrm{C}$ transit time and turnover time increase in response to climate warming and decrease in response to rising atmospheric $\left[\mathrm{CO}_{2}\right]$, their deviations increase with time in all three climate change scenarios. In 2100, the deviations are high in tropical regions under the climate warming scenario (S1) and rising atmospheric $\left[\mathrm{CO}_{2}\right]$ scenario (S2) and in high-latitude regions under S1 and the combined change scenario (S3). Knowledge about the deviation between $\mathrm{C}$ transit time and turnover time in different regions under different scenarios (warming and $\left[\mathrm{CO}_{2}\right]$ rising) is useful for us to understand time characteristics of the ecosystem carbon dynamics. When we lump all pools and fluxes together to calculate turnover time by stock over flux, the time characteristic is different from that of transit time when individual pools and fluxes are considered within a networked compartmental system. Thus, our results provide information on how turnover time in the future could deviate from transit time in specific regions and natural ecosystems under different climate change scenarios.

The changes in $\mathrm{C}$ transit time result from both the $\mathrm{C}$ age structure changes and composition changes in respired $\mathrm{C}$ in multi-pool ecosystems. The $\mathrm{C}$ age structure changes mainly depend on young $\mathrm{C}$ replenishment from external $\mathrm{C}$ input. The composition change is due to differential responses of various $\mathrm{C}$ pools to climate warming and rising atmospheric $\left[\mathrm{CO}_{2}\right]$. However, $\mathrm{C}$ turnover time assumes the ecosystem to be one homogeneous pool, and it does not account for changes in age structure and contribution fractions of different pools to ecosystem respiration. Thus, $\mathrm{C}$ transit time is a better parameter than $\mathrm{C}$ turnover time to characterize the $\mathrm{C}$ cycle in multi-pool ecosystems, especially when they are at transient states. 
However, $\mathrm{C}$ transit time cannot be easily measured because it requires information of the $\mathrm{C}$ age structure and composition of respired C. Both of them are usually not measurable in field studies. Radiocarbon ${ }^{14} \mathrm{C}$ measurement in the field has the potential to offer information on mean $\mathrm{C}$ ages in various pools. It is not easy, either, to estimate contribution fractions of different pools from measured ecosystem or soil respiration to respired $\mathrm{C}$. We may have to combine compartment models with different types of measurements via data assimilation techniques to estimate both age structure and composition of respired $\mathrm{C}$ before we can estimate ecosystem $\mathrm{C}$ transit time.

Data availability. The CABLE code is available online https://trac. nci.org.au/trac/cable (Kowalczyk et al., 2006; Wang et al., 2010, 2011). C age and transit time data are generated using the NCAR Command Language (NCL) script, which is available online http: //www2.nau.edu/luo-lab/download/Lu_2018_Biogeosciences.php.

Supplement. The Supplement related to this article is available online at: https://doi.org/10.5194/bg-15-6559-2018-supplement.

Author contributions. XL, YW, and YL designed the study. XL conducted the model simulations. XL, YW, YL, and LJ analysed the results together. All co-authors were involved in writing the paper and contributed to the study with feedback and critique.

Competing interests. The authors declare that they have no conflict of interest.

Acknowledgements. This research was financially supported by the postdoctoral fellowship from the CSIRO Office of Chief Executive to Xingjie Lu, U.S. Department of Energy grants DE-SC0008270 and DE-SC0014085, and US National Science Foundation (NSF) grants EF-1807529 and OIA-1301789 to Yiqi Luo EcoLab.

Edited by: Alexey V. Eliseev

Reviewed by: two anonymous referees

\section{References}

Bolin, B. and Rodhe, H.: A note on Concepts of Age Distribution and Transit-Time in Natural Reservoirs, Tellus, 25, 58-62, 1973.

Campbell, B. D., Stafford Smith, D. M., and McKeon, G. M.: Elevated $\mathrm{CO}_{2}$ and water supply interactions in grasslands: A pastures and rangelands management perspective, Global Change Biol., 3, 177-187, 1997.

Carvalhais, N., Forkel, M., Khomik, M., Bellarby, J., Jung, M., Migliavacca, M., Mu, M. Q., Saatchi, S., Santoro, M., Thurner,
M., Weber, U., Ahrens, B., Beer, C., Cescatti, A., Randerson, J. T., and Reichstein, M.: Global covariation of carbon turnover times with climate in terrestrial ecosystems, Nature, 514, 213 217, https://doi.org/10.1038/nature13731, 2014.

Chen, S. T., Huang, Y., Zou, J. W., and Shi, Y. S.: Mean residence time of global topsoil organic carbon depends on temperature, precipitation and soil nitrogen, Global Planet. Change, 100, 99108, 2013.

Cox, P. M., Betts, R. A., Collins, M., Harris, P. P., Huntingford, C., and Jones, C. D.: Amazonian forest dieback under climatecarbon cycle projections for the 21st century, Theor. Appl. Climatol., 78, 137-156, 2004.

Cox, P. M., Pearson, D., Booth, B. B., Friedlingstein, P., Huntingford, C., Jones, C. D., and Luke, C. M.: Sensitivity of tropical carbon to climate change constrained by carbon dioxide variability, Nature, 494, 341-344, https://doi.org/10.1038/nature11882, 2013.

Eriksson, E.: Compartment models and reservoir, Annu. Rev. Ecol. Syst., 2, 67-84, 1971

Farquhar, G. D., Caemmerer, S. V., and Berry, J. A.: A Biochemical-Model of Photosynthetic $\mathrm{CO}_{2}$ Assimilation in Leaves of C-3 Species, Planta, 149, 78-90, https://doi.org/10.1007/Bf00386231, 1980.

Friend, A. D., Lucht, W., Rademacher, T. T., Keribin, R., Betts, R., Cadule, P., Ciais, P., Clark, D. B., Dankers, R., Falloon, P. D., Ito, A., Kahana, R., Kleidon, A., Lomas, M. R., Nishina, K., Ostberg, S., Pavlick, R., Peylin, P., Schaphoff, S., Vuichard, N., Warszawski, L., Wiltshire, A., and Woodward, F. I.: Carbon residence time dominates uncertainty in terrestrial vegetation responses to future climate and atmospheric $\mathrm{CO}_{2}$, P. Natl. Acad. Sci. USA, 111, 3280-3285, https://doi.org/10.1073/pnas.1222477110, 2014.

Gaudinski, J. B., Trumbore, S. E., Davidson, E. A., and Zheng, S. H.: Soil carbon cycling in a temperate forest: radiocarbon-based estimates of residence times, sequestration rates and partitioning of fluxes, Biogeochemistry, 51, 33-69, 2000.

He, Y. J., Trumbore, S. E., Torn, M. S., Harden, J. W., Vaughn, L. J. S., Allison, S. D., and Randerson, J. T.: Radiocarbon constraints imply reduced carbon uptake by soils during the 21st century, Science, 353, 1419-1424, https://doi.org/10.1126/science.aad4273, 2016.

Huang, Y. Y., Lu, X. J., Shi, Z., Lawrence, D., Koven, C. D., Xia, J. Y., Du, Z. G., Kluzek, E., and Luo, Y. Q.: Matrix approach to land carbon cycle modeling: A case study with the Community Land Model, Global Change Biol., 24, 1394-1404, 2018.

Hurrell, J. W., Holland, M. M., Gent, P. R., Ghan, S., Kay, J. E., Kushner, P. J., Lamarque, J. F., Large, W. G., Lawrence, D., Lindsay, K., Lipscomb, W. H., Long, M. C., Mahowald, N., Marsh, D. R., Neale, R. B., Rasch, P., Vavrus, S., Vertenstein, M., Bader, D., Collins, W. D., Hack, J. J., Kiehl, J., and Marshall, S.: The Community Earth System Model A Framework for Collaborative Research, B. Am. Meteorol. Soc., 94, 1339-1360, https://doi.org/10.1175/Bams-D-12-00121.1, 2013.

Kelly, R. H., Parton, W. J., Hartman, M. D., Stretch, L. K., Ojima, D. S., and Schimel, D. S.: Intra-annual and interannual variability of ecosystem processes in shortgrass steppe, J. Geophys. Res.-Atmos., 105, 20093-20100, https://doi.org/10.1029/2000jd900259, 2000. 
Kirilenko, A. P. and Solomon, A. M.: Modeling dynamic vegetation response to rapid climate change using bioclimatic classification, Clim. Change, 38, 15-49, 1998.

Koven, C. D., Riley, W. J., Subin, Z. M., Tang, J. Y., Torn, M. S., Collins, W. D., Bonan, G. B., Lawrence, D. M., and Swenson, S. C.: The effect of vertically resolved soil biogeochemistry and alternate soil $\mathrm{C}$ and $\mathrm{N}$ models on C dynamics of CLM4, Biogeosciences, 10, 7109-7131, https://doi.org/10.5194/bg-107109-2013, 2013.

Kowalczyk, E., Wang, Y., Law, R., Davies, H., McGregor, J., and Abramowitz, G.: The CSIRO Atmosphere Biosphere Land Exchange (CABLE) model for use in climate models and as an offline model, CSIRO Marine and Atmospheric Research Paper, 13, 1-37, 2006

Le Quéré, C., Andrew, R. M., Friedlingstein, P., Sitch, S., Pongratz, J., Manning, A. C., Korsbakken, J. I., Peters, G. P., Canadell, J. G., Jackson, R. B., Boden, T. A., Tans, P. P., Andrews, O. D., Arora, V. K., Bakker, D. C. E., Barbero, L., Becker, M., Betts, R. A., Bopp, L., Chevallier, F., Chini, L. P., Ciais, P., Cosca, C. E., Cross, J., Currie, K., Gasser, T., Harris, I., Hauck, J., Haverd, V., Houghton, R. A., Hunt, C. W., Hurtt, G., Ilyina, T., Jain, A. K., Kato, E., Kautz, M., Keeling, R. F., Klein Goldewijk, K., Körtzinger, A., Landschützer, P., Lefèvre, N., Lenton, A., Lienert, S., Lima, I., Lombardozzi, D., Metzl, N., Millero, F., Monteiro, P. M. S., Munro, D. R., Nabel, J. E. M. S., Nakaoka, S.-I., Nojiri, Y., Padin, X. A., Peregon, A., Pfeil, B., Pierrot, D., Poulter, B., Rehder, G., Reimer, J., Rödenbeck, C., Schwinger, J., Séférian, R., Skjelvan, I., Stocker, B. D., Tian, H., Tilbrook, B., Tubiello, F. N., van der Laan-Luijkx, I. T., van der Werf, G. R., van Heuven, S., Viovy, N., Vuichard, N., Walker, A. P., Watson, A. J., Wiltshire, A. J., Zaehle, S., and Zhu, D.: Global Carbon Budget 2017, Earth Syst. Sci. Data, 10, 405-448, https://doi.org/10.5194/essd-10-405-2018, 2018.

Leuning, R.: Temperature dependence of two parameters in a photosynthesis model, Plant Cell Environ., 25, 1205-1210, https://doi.org/10.1046/j.1365-3040.2002.00898.x, 2002.

Leuzinger, S., Luo, Y. Q., Beier, C., Dieleman, W., Vicca, S., and Korner, C.: Do global change experiments overestimate impacts on terrestrial ecosystems?, Trends Ecol. Evol., 26, 236-241, 2011

Li, J. D., Wang, Y. P., Duan, Q. Y., Lu, X. J., Pak, B., Wiltshire, A., Robertson, E., and Ziehn, T.: Quantification and attribution of errors in the simulated annual gross primary production and latent heat fluxes by two global land surface models, J. Adv. Model. Earth Sy., 8, 1270-1288, https://doi.org/10.1002/2015ms000583, 2016.

Liang, J., Xia, J., Shi, Z., Jiang, L., Ma, S., Lu, X., Mauritz, M., Natali, S. M., Pegoraro, E., and Penton, C. R.: Biotic responses buffer warming-induced soil organic carbon loss in Arctic tundra, Global Change Biol., 24, 4946-4959, https://doi.org/10.1111/gcb.14325, 2018.

Luo, Y. and Weng, E.: Dynamic disequilibrium of the terrestrial carbon cycle under global change, Trends Ecol. Evol., 26, 96-104, https://doi.org/10.1016/j.tree.2010.11.003, 2011.

Luo, Y., Shi, Z., Lu, X., Xia, J., Liang, J., Jiang, J., Wang, Y., Smith, M. J., Jiang, L., Ahlström, A., Chen, B., Hararuk, O., Hastings, A., Hoffman, F., Medlyn, B., Niu, S., Rasmussen, M., Todd-Brown, K., and Wang, Y.-P.: Transient dynamics of terrestrial carbon storage: mathematical foundation and its applica- tions, Biogeosciences, 14, 145-161, https://doi.org/10.5194/bg14-145-2017, 2017.

Luo, Y. Q., Wu, L. H., Andrews, J. A., White, L., Matamala, R., Schafer, K. V. R., and Schlesinger, W. H.: Elevated $\mathrm{CO}_{2}$ differentiates ecosystem carbon processes: Deconvolution analysis of Duke Forest FACE data, Ecol. Monogr., 71, 357-376, https://doi.org/10.1890/00129615(2001)071[0357:Ecdecp]2.0.CO;2, 2001.

Luo, Y. Q., Gerten, D., Le Maire, G., Parton, W. J., Weng, E. S., Zhou, X. H., Keough, C., Beier, C., Ciais, P., Cramer, W., Dukes, J. S., Emmett, B., Hanson, P. J., Knapp, A., Linder, S., Nepstad, D., and Rustad, L.: Modeled interactive effects of precipitation, temperature, and $\left[\mathrm{CO}_{2}\right]$ on ecosystem carbon and water dynamics in different climatic zones, Global Change Biol., 14, 19861999, 2008.

Manzoni, S., Katul, G. G., and Porporato, A.: Analysis of soil carbon transit times and age distributions using network theories, J. Geophys. Res.-Biogeo., 114, G04025, https://doi.org/10.1029/2009jg001070, 2009.

Masek, J. G.: Stability of boreal forest stands during recent climate change: evidence from Landsat satellite imagery, J. Biogeogr., 28, 967-976, 2001.

McCulley, R. L., Archer, S. R., Boutton, T. W., Hons, F. M., and Zuberer, D. A.: Soil respiration and nutrient cycling in wooded communities developing in grassland, Ecology, 85, 2804-2817, https://doi.org/10.1890/03-0645, 2004.

Nir, A. and Lewis, S.: Tracer Theory in Geophysical Systems in Steady and Non-Steady State.1., Tellus, 27, 372-383, 1975.

Norby, R. J. and Luo, Y. Q.: Evaluating ecosystem responses to rising atmospheric $\mathrm{CO}_{2}$ and global warming in a multi-factor world, New Phytol, 162, 281-293, 2004.

Olson, J. S.: Energy-Storage and Balance of Producers and Decomposers in Ecological-Systems, Ecology, 44, 322-331, https://doi.org/10.2307/1932179, 1963.

Qian, T. T., Dai, A., Trenberth, K. E., and Oleson, K. W.: Simulation of global land surface conditions from 1948 to 2004. Part I: Forcing data and evaluations, J. Hydrometeorol., 7, 953-975, https://doi.org/10.1175/Jhm540.1, 2006.

Raich, J. W. and Schlesinger, W. H.: The Global Carbon-Dioxide Flux in Soil Respiration and Its Relationship to Vegetation and Climate, Tellus B, 44, 81-99, https://doi.org/10.1034/j.16000889.1992.t01-1-00001.x, 1992.

Rasmussen, M., Hastings, A., Smith, M. J., Agusto, F. B., ChenCharpentier, B. M., Hoffman, F. M., Jiang, J., Todd-Brown, K. E. O., Wang, Y., Wang, Y. P., and Luo, Y. Q.: Transit times and mean ages for nonautonomous and autonomous compartmental systems, J. Math. Biol., 73, 1379-1398, 2016.

Ryan, M. G.: Effects of Climate Change on Plant Respiration, Ecol. Appl., 1, 157-167, https://doi.org/10.2307/1941808, 1991.

Sanderman, J., Amundson, R. G., and Baldocchi, D. D.: Application of eddy covariance measurements to the temperature dependence of soil organic matter mean residence time, Global Biogeochem. Cy., 17, 1061, https://doi.org/10.1029/2001gb001833, 2003.

Sierra, C. A., Muller, M., Metzler, H., Manzoni, S., and Trumbore, S. E.: The muddle of ages, turnover, transit, and residence times in the carbon cycle, Global Change Biol., 23, 1763-1773, https://doi.org/10.1111/gcb.13556, 2016.

Sitch, S., Smith, B., Prentice, I. C., Arneth, A., Bondeau, A., Cramer, W., Kaplan, J. O., Levis, S., Lucht, W., Sykes, M. T., 
Thonicke, K., and Venevsky, S.: Evaluation of ecosystem dynamics, plant geography and terrestrial carbon cycling in the LPJ dynamic global vegetation model, Global Change Biol., 9, 161185, https://doi.org/10.1046/j.1365-2486.2003.00569.x, 2003.

Soja, A. J., Tchebakova, N. M., French, N. H. F., Flannigan, M. D., Shugart, H. H., Stocks, B. J., Sukhinin, A. I., Parfenova, E. I., Chapin, F. S., and Stackhouse, P. W.: Climate-induced boreal forest change: Predictions versus current observations, Global Planet. Change, 56, 274-296, 2007.

Taylor, J. A. and Lloyd, J.: Sources and Sinks of Atmospheric $\mathrm{CO}_{2}$, Aust. J. Bot., 40, 407-418, https://doi.org/10.1071/Bt9920407, 1992.

Trumbore, S.: Age of soil organic matter and soil respiration: Radiocarbon constraints on belowground C dynamics, Ecol. Appl., 10, 399-411, 2000.

Wang, Y., Amundson, R., and Trumbore, S.: The impact of land use change on $\mathrm{C}$ turnover in soils, Global Biogeochem. Cy., 13, 47-57, 1999.

Wang, Y. P. and Leuning, R.: A two-leaf model for canopy conductance, photosynthesis and partitioning of available energy I: Model description and comparison with a multi-layered model, Agr. Forest. Meteorol., 91, 89-111, https://doi.org/10.1016/S0168-1923(98)00061-6, 1998.

Wang, Y. P., Law, R. M., and Pak, B.: A global model of carbon, nitrogen and phosphorus cycles for the terrestrial biosphere, Biogeosciences, 7, 2261-2282, https://doi.org/10.5194/bg-7-22612010, 2010.

Wang, Y. P., Kowalczyk, E., Leuning, R., Abramowitz, G., Raupach, M. R., Pak, B., van Gorsel, E., and Luhar, A.: Diagnosing errors in a land surface model (CABLE) in the time and frequency domains, J. Geophys. Res.-Biogeol., 116, G01034, https://doi.org/10.1029/2010JG00138, 2011.
Xia, J. Y., Luo, Y. Q., Wang, Y.-P., Weng, E. S., and Hararuk, O.: A semi-analytical solution to accelerate spin-up of a coupled carbon and nitrogen land model to steady state, Geosci. Model Dev., 5, 1259-1271, https://doi.org/10.5194/gmd-5-1259-2012, 2012.

$\mathrm{Xu}$, T., White, L., Hui, D. F., and Luo, Y. Q.: Probabilistic inversion of a terrestrial ecosystem model: Analysis of uncertainty in parameter estimation and model prediction, Global Biogeochem. Cy., 20, GB2007, https://doi.org/10.1029/2005GB002468, 2006.

Yan, Y., Zhou, X., Jiang, L., and Luo, Y.: Effects of carbon turnover time on terrestrial ecosystem carbon storage, Biogeosciences, 14 , 5441-5454, https://doi.org/10.5194/bg-14-5441-2017, 2017.

Zhang, Q., Wang, Y. P., Pitman, A. J., and Dai, Y. J.: Limitations of nitrogen and phosphorous on the terrestrial carbon uptake in the 20th century, Geophys. Res. Lett., 38, L22701, https://doi.org/10.1029/2011GL049244, 2011.

Zhang, X. Z., Rayner, P. J., Wang, Y. P., Silver, J. D., Lu, X. J., Pak, B., and Zheng, X. G.: Linear and nonlinear effects of dominant drivers on the trends in global and regional land carbon uptake: 1959 to 2013, Geophys. Res. Lett., 43, 1607-1614, 2016.

Zhou, T. and Luo, Y. Q.: Spatial patterns of ecosystem carbon residence time and NPP-driven carbon uptake in the conterminous United States, Global Biogeochem. Cy., 53, 1229-1240, https://doi.org/10.1029/2007GB002939, 2008. 